\title{
CARTOGRAPHIC REPRESENTATIONS IN EARLY EIGHTEENTH CENTURY BAROQUE MALTA
}

\author{
Lino BIANCO ${ }^{1}$
}

DOI: 10.21163/GT_2017.121.01

\begin{abstract}
:
As contracts are fact-specific statements so are the cartographic representations attached to them. This article addresses such representations dating to early eighteenth century Baroque Malta. It focuses on a specific public deed which includes a sketch plan covering a large territory. This representation, which is countersigned by 'periti', has no scale bar but includes orientation and annotations with respect to the extent of the territory subject of the deed. Through these annotations which included landmarks and linear measurements, the boundaries of the property were reinterpreted. Whereas the current interpretation is $35 \%$ in excess of the superficial area stated in the deed, a re-interpretation led to a variation of less than $1 \%$. This illustrates that historical figurative cartographic representations are accurate, fact-specific legal documents with minimal variations.
\end{abstract}

Key-words: Cartographic representation, Architecture, Baroque, Perit, Malta.

\section{INTRODUCTION}

This paper is based on a study of a number of early eighteenth century cartographic representations attached to contracts made in the Maltese Archipelago, notably in the islands of Malta and Gozo. It specifically addresses the interpretation of a sketch plan attached to a deed in Malta entered in the year 1737. The territory covered by this representation forms part of the property of the Abbazia di San Antonio, founded by Cosmana Navarra as per act entered in the records of Notary Nicola Allegretto on 25 August 1675. This land is located at Ta' Vardati, in the limits of the village of Qala in Gozo, the sister island of Malta. From the year 1530 till 1798 the Maltese archipelago was the seat of the Order of St John of Jerusalem. The interpretation of this sketch plan by the Curia of the Archdiocese of Malta on the official survey sheets (1965) has a significant snag: the resulting superficial area of the property is more than $35 \%$ that stated in the deed. Given that contracts are fact-specific contractual agreements so are plans attached to same. The variation in the resulting area is significant. The scope of this paper is to put forward a re-interpretation of the cartographic representation following retracing based on the information contained in the original.

\section{CARTOGRAPHIC REPRESENTATION}

\subsection{The sketch plan}

This deed makes reference to cartographic representation of a territory having a superficial area of 21 salmi and 2 tumoli, hereby reproduced in Fig. 1 with the same orientation as in the original folio. This site location sketch plan was submitted by 'Periti' Joseph Pisano and Felix Abela on $26^{\text {th }}$ January 1737 "in qua totoque negotio bene

\footnotetext{
${ }^{1}$ University of Malta, 2080 Msida, Malta, lino.bianco@um.edu.mt.
} 
fideliterque gessisse", translated as "in which rightly and faithfully shows the business transacted". This cartographic representation, which neither makes reference to a scale nor includes one, states the geographical location of three landmarks: (i) "La Levante con spiaggia" (the coast facing east), (ii) a "fortino" (coastal battery) and (iii) a "fontana" (spring). It also states the length of territory facing north and south, specifically 240 and 443 canes respectively, and ties the latter with landmark (ii).

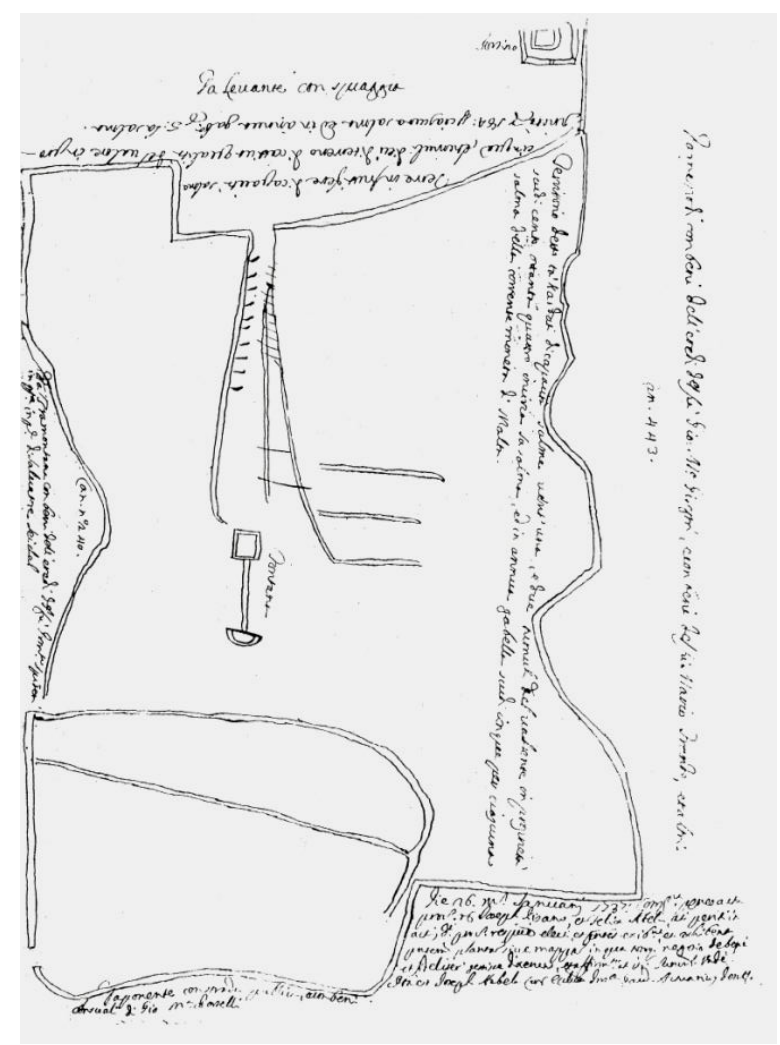

Fig. 1 Cartographic representation of the territory at Ta' Vardati, in the limits of Qala, Gozo. Dated $26^{\text {th }}$ January 1737 , it is attached and forms an integral part of the deed entered on $17^{\text {th }}$ March 1737.

The following measurements and conversion factors are relevant for this study: linear: 1 cane $\quad 2.292$ yards (Hoppen 1979: p. 169)

1 cane $: 6.876$ feet

1 cane $\quad: 2.088$ metres (after Doursther 1840: p. 83)

square: $\quad 1$ salma $: 16$ tumoli

1 tumolo: 256 square canes

1 square cane: 4.360 square metres (after Doursther, 1840) 


\subsection{Interpretation by the Curia}

The interpretation submitted by the Curia was indicated at scale 1:2,500 on the ordnance survey sheets 3887, 3888, 4087 and 4088 (Ordnance Survey, 1965). These survey sheets are based on the air photographs undertaken in August 1957 and field revised by the Office of the Public Works, Malta, in 1964. Originally drawn at scale 1:2,500, they are very accurate (Fig. 3). The outline of the site as stated by the Curia varies from the information contained in the original representation on two counts, linear and square dimensions, the latter computed through the grid square method, an elementary yet effective technique used in calculating the area contained in a given space/confines/boundary/territory. This method involves having a pre-set/pre-designed/pre-established grid. Assigning a scale to the grid, say 1 millimetre to 250 metres (that is 1 square millimetre to 62,500 square metres or 0.0625 square kilometres), one multiply the number of squares or part thereof which covers a given space/confines/boundary/territory by the set scale.

The superficial area of the site in the interpretation made by the Curia amounted to 34 salmi and 3 tumoli (547 tumoli) less the 90 tumoli stated separately on the sketch plan attached to the deed, that is, 28 salmi and 9 tumoli (Table 1). The system of linear land units prevalent in earlier part of nineteenth century Malta stated in the authoritative publication by Robert Montgomery Martin (1843: p. 587), was used. For the conversion of cane into metres, Pouchet's factor of 2.088 as reported in a publication issued almost contemporaneously by Horace Doursther (1840: p. 83) was used.

Table 1.

Dimensions of the site as per (i) deed entered on 17th March 1737 and (ii) the interpretation given by the Curia (metric dimensions are rounded to four significant figures).

\begin{tabular}{|c|c|c|c|c|}
\hline \multirow{2}{*}{ Linear } & \multicolumn{2}{|c|}{ Contract } & \multicolumn{2}{c|}{ Curia } \\
\cline { 2 - 5 } & 443 canes & 925.0 metres & 510 canes & 1065.0 metres \\
\hline Square & 240 canes & 501.1 metres & 300 canes & 626.4 metres \\
\hline
\end{tabular}

\section{HISTORIOGRAPHICAL AND GEOCULTURAL CONTEXTS}

\subsection{Background}

Coastal fortifications were strategic to the Order's defense policy in the first decades of the eighteenth century (Spiteri, 2008). All new public works were the responsibility of the Resident Engineer of the Order who, at the time, was the French national Charles François de Mondion (De Lucca 1980: p.32). He arrived in Malta in 1715 as deputy head of the French Military Mission which was led by Réné Jacob de Tigné (De Lucca 2003: p. 2). He, recommended to the Order by the King of France, studied and trained under Sébastien Le Prestre de Vauban, the main French military engineer at the time (De Lucca 1980: p. 2627). As per Archives of the Order of Malta, the Grand Master at the time, António Manoel de Vilhena, thought of Mondion as a person "who merits all esteem for his singular virtues and unparalleled experience in these matters [of designing new fortresses/batteries]" (De Lucca 1980: p. 32). Vilhena's term in office was from 1722 until his death in December 1736; Mondion passed away in 1733 (De Lucca 2003: p. 14).

In order to retrace the 1737 cartographic representation one has to place it within both the historiographical and geocultural contexts in which it was drawn up. A number of observations are worth noting. This sketch plan is dated $26^{\text {th }}$ January 1737 . The coastal 
battery had almost been completed by then. A manuscript of the Library of the Order of St. John cited in Hoppen (1979: p. 207, fn. 23) states that the construction of St Anthony's battery commenced in 1731. An inscription on the entrance to the battery bears the date 1732 and states "Nel Governo del Cav Fra Paolo Antonio de Viguer", the Governor of Gozo from 1732 to 1734 (Samut-Tagliaferro, 1993). Although almost completed by the end of 1732, minor work was still in hand. The surplus quantities of pozzolana were transported from the battery back to the Gozo Citadel by the end of 1732 whilst by April 1734 the escutcheons on the entrance gate were completed (Spiteri).

The battery at Qala point is Ras il-Qala battery, locally known as St Anthony's Battery. At the time of the deed under study no name to the battery is stated. It has been argued that it was called after this saint in honour of the Grand Master at the time who had offered to fund its construction (Spiteri). No research was ever conducted as to whether it was derived from the name of the Abbazia founded by Navarra, a foundation with extensive immovable property for a noble Catholic cause at the time of the Ottoman Empire.

The battery is erected in Lower Coralline Limestone, the oldest geological unit in the archipelago, and which outcrops on site and along the coast of Qala (Office of the Prime Minister, 1993). In addition to this lithostratigraphic unit, three more formations are present in the area, namely, Globigerina Limestone, Blue Clay and the overlying Greensand. This geological setting includes the possibility of encountering springs surging from the perched aquifer which occurs on top of the Blue Clay (Morris 1952: p. 55-56) and thus accounts for landmark (iii), the "fontana" (spring) noted in the sketch plan.

\subsection{Lands at Ta` Vardati}

The territory at Ta' Vardati forms part of the property of the Abbazia di San Antonio. Pisano and Abela were the 'periti' who submitted under oath various plans of buildings and landed property belonging to the said Abbazia. The 'perit' is the Maltese profession of architect-engineer introduced by the Order in the sixteenth century and developed further in the eighteenth century (De Lucca, 1975; Spiteri \& Borg, 2015). All plans stated/indicated the site area, the market value of the property being transacted and the orientation. The assignment carried out by these 'periti' is typical for the 'perit' of the eighteenth century. The practises of 'periti' was defined in the Codice Manoel de Vilhena (Manoel de Vilhena Code) issued in 1724. Citing this Code (1794: T. 24, para. 63, fn. 120), Spiteri and Borg note that 'periti' and 'agrimensori' are "those who completed surveys and valuation of urban as well as rural properties and reported on matters of property litigations" (2015, p. 131-132). Documents pertaining to the period show that 'periti' started to be involved, among other things, to sit on various ecclesiastical boards, to draw up plans and valuations of immovable property and to draft plans and reports for notarial contracts (De Lucca 1975: p. 434).

All plans of immovable properties attached to the contracts of the Abbazia except the ones such as the cartographic representation under study, contain a scale rule. A scale bar implies that one may dimension the plan on site. The absence of a scale rule implies that the plan was meant to be a sketch. This does not imply that the plan is not correct or that it cannot be interpreted accurately. The area at Ta' Vardati is too large compared to the other landed properties signed by the said 'periti'. They identified key landmarks on site, namely the battery, the fountain and the location of the beach/coast, and stated two linear measurements one of which is tied with the battery, a permanent feature on site. Lengths are not stated in the other plans. By identifying these features and noting the absolute linear dimensions and the site area, the perimeter of the site was accurately retraced (Fig. 2). 


\section{REINTERPRETATION}

\subsection{Retracing the representation}

Using the cartographic representation attached to the contract and the information contained therein, the following interpretation was put forward in Fig. 3. The drafting involved the following five steps:

1. Taking the apex of the coastal battery, marked $f_{l}$ in green in Fig. 2, as a centre and draw an arc of a radius equivalent to 443 canes (925.0 metres);

2. The wall which runs inland from the battery, marked $w_{1}$ in brown in Fig. 2 , is drawn until this feature intersects the arc;

3. The feature marked in red and labelled $f_{2}$ in Fig. 2, which is also present in the topographical survey of Gozo undertaken in 1897 (Intelligence Division War Office, 1899), is matched with a similar feature in the 1968 survey sheets. Although this late nineteenth century map is plotted at a scale of two inches to a mile, the detail is based on a triangulation executed from the six inches to a mile map of the Malta Public Works Department;

4. From the intersection of this feature with the wall along the north as centre, an arc equivalent to 240 canes (501.1 metres) is drawn along the same wall; and

5. From the intersection of the arc, wall $w_{2}$ is plotted along the field boundaries and takes into account suggestive indents as per contract plan. It is joined to the wall commencing from the battery.

Applying the grid square method, the resulting area is 340 tumoli or 21 salmi and 4 tumoli (377,200 square metres). This is more approximate to the superficial area stated in the deed (21 salmi +2 tumoli or 377,200 square metres) than that arising from the interpretation by the Curia ( 28 salmi +9 tumoli or 510,100 square metres).

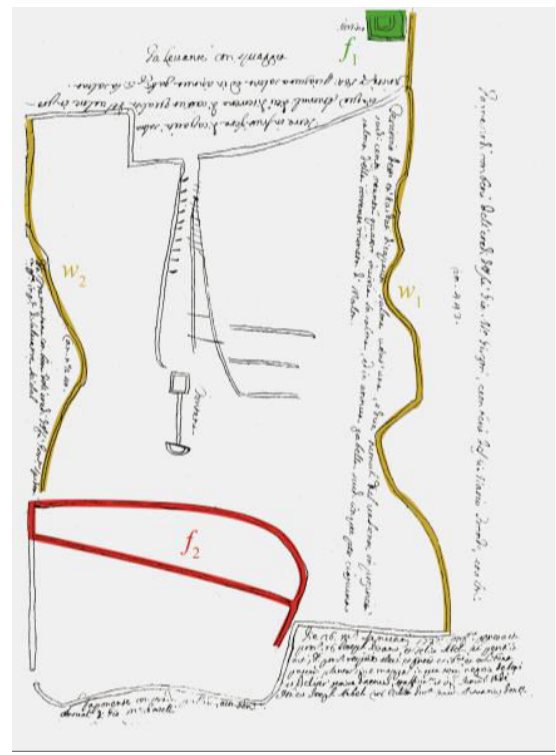

Fig. 2 Re-plotting of the cartographic representation of the territory at Ta' Vardati, limits of Qala, Gozo. 


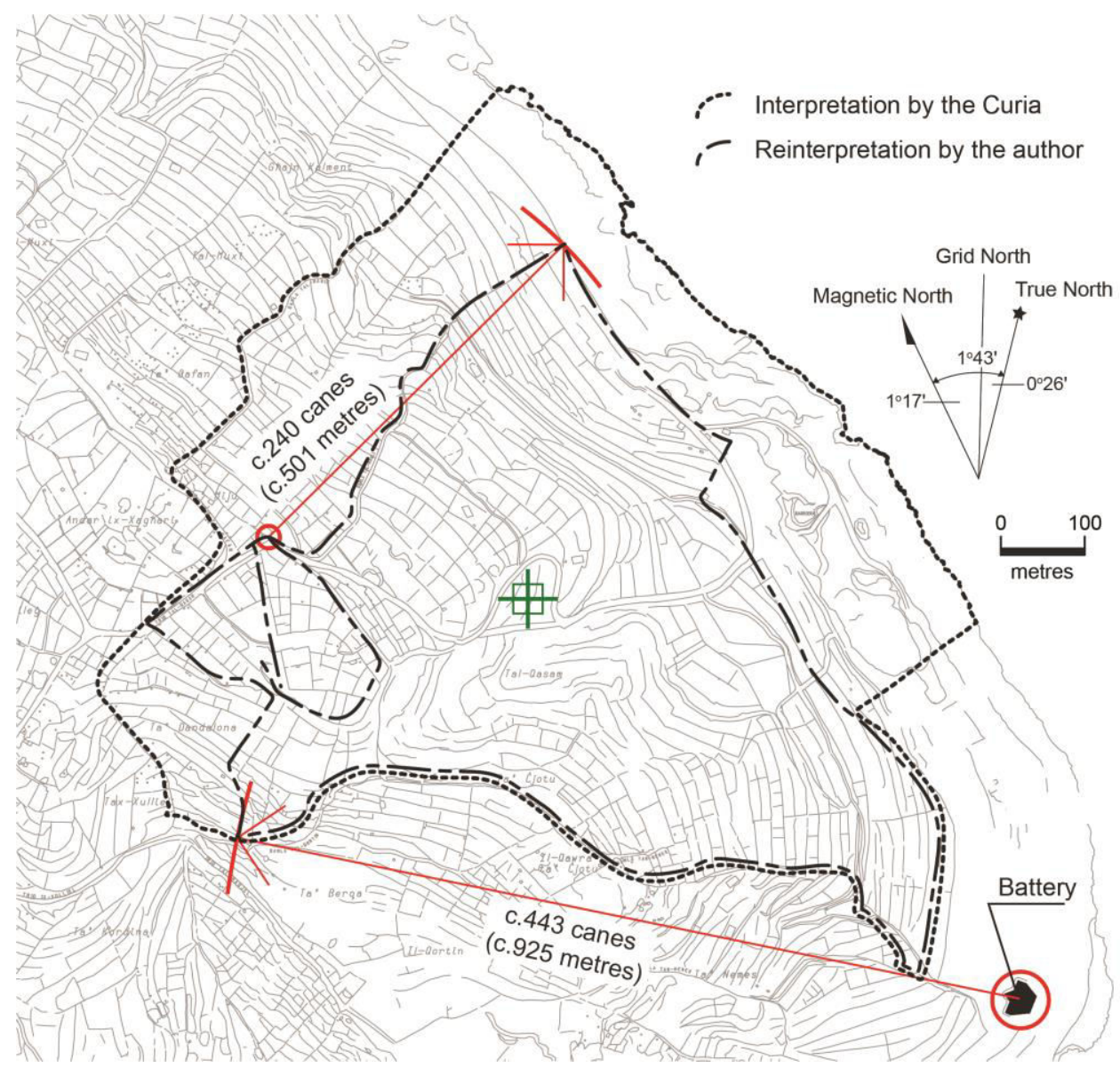

Fig. 3 Re-interpretation of the cartographic representation shown in Fig. 1 on the Ordnance Survey (1965) sheets of the area; the coordinates at the centre are circa UTM ED50 439574E, 3988460N).

\subsection{Discussion}

An essential element in cartography is visual communication which makes use of standard notations for interpreting information contained in the representation (Vartic, 2015). The Baroque period is "characterized ... by eagerness to integrate spaces in a single unit, whether urban or landscape" (Gomis \& Turón, 2014: p. 38). Gomis \& Turón note that "La Pianta Grande di Roma" (The Great Map of Rome) by Giambattista Nolli, a work which commenced in 1736 and was published 12 years later, is the best example to illustrate cartographical representations aimed to accurately plot detailed boundaries of the districts of the city (Gomis \& Turón, 2014). They also noted that Nolli had made use of Guarino Guarini's plans published in 1737 (Guarini, 1737). Despite its impressively precise representation, only $18 \%$ of the printed copies were sold and, citing Bosselmann, 'the general public preferred a more figurative image rather than "spending money on a plan whose main merit was to show the exact dimensions of all parts of the city"' (Bosselmann 1998: p. 21; Gomis \& Turón, 2014: p. 39). 
Whilst, for small tenements, early eighteenth century cartographic images undertaken by Pisano and Abela are visual expression of the property being represented, this is not the case with large territory of land. The latter, as the case with the 1737 deed, are graphical ones with annotations sufficient to project the configuration of the property on site. It is a visual representation of the extent of the property with respect to the geocultural landscape; it contains information/facts which need to be communicated to trace the land being subject of the deed. The Ta' Vardati sketch plan illustrates the communication and technical skills used in representation. The image is accurate in identifying specific features. It was not meant to be used by the general public but by specialists able to translate the contents therein. Yet, it is fact-specific as are the cartographic representations of the period with respect to smaller tenements.

\section{CONCLUSIONS}

The interpretation by the Curia does not correspond to the plan attached to the deed since both the linear and square dimensions do no tally. The variation in the percentage superficial area from that stated in the contract, excluding the 90 tumoli, is $+35 \%(=\{[(457-$ $\left.\left.338) / 338]^{*} 100\right\} \%\right)$.

Following historical research through contracts at the time signed by the same 'periti' for the Abbazia and on the territory subject of this study, the extent of the property indicated on the cartographic representation was remapped on the official survey sheets. The resultant variation in percentage area of the reinterpretation of this sketch plan, which addresses all annotations included in the original, is less than $+1 \% \quad(=\{[(340-$ $\left.338) / 338]^{*} 100\right\} \%$ ). The margin of error is insignificant and thus one may conclude that the resultant tallies with the square dimensions stated in the representation.

Early eighteenth century cartographic representations of large tracts of land attached to contracts are fact-specific. Although not graphically refined, they are correct graphic representation of the territory. Albeit, as a visual expression, the configuration does not match the profile on site, the annotations contained are sufficient to plot accurately the extent of the immovable property through quasi objective criteria based on features referred therein.

\section{R E F E R E N C E S}

Bosselmann, P. (1998) Representation of places: Reality and realism in city design. Berkeley, California: University of California Press.

Codice Manoel de Vilhena (1724) Leggi, e Costituzioni Prammaticali.

De Lucca, D. (1975) The Maltese 'Perit' in History, Melita Historica-Malta Historical Society, 6 (4), 431-436.

De Lucca, D. (1980) French Military Engineers in Malta during the 17th and 18th Centuries, Melita Historica- The Historical Society, 8 (1), 23-33.

De Lucca, D. (2003) Mondion: The achievement of a French Military Engineer working in Malta in the early eighteenth century, Sta Venera, Malta: Midsea Books Ltd.

Doursther, H. (1840) Dictionnaire universel des poids et mesures anciens et modernes, contenat des tables des monnaies de tous les pays. Brussels: M. Hayez, Imprimeur de l'Académie Royale. Reprinted by Meridian Publishing Company, Amsterdam, 1965.

Gomis, J. \& Turón C. (2014) Conceptual and instrumental influences in the graphic representation of urban planning: from ancient times to the baroque, Geographia Technica, 9 (2), 30-43. 
Guarini, G. (1737) Architettura Civile del padre D. Guarino Guarini chierico regolare. Opera postuma dedicata a Sua Sacra Reale Maestà. Torino: Apresso Gianfrancesco Mairesse all'Insegna di Santa Teresa di Gesù.

Hoppen, A. (1979) The Fortifications of Malta by the Order of St. John. Edinburgh: Scottish Academic Press.

Intelligence Division War Office (1899) Map of the Island of Gozo, 1395.

Martin, R. M. (1843) History of the Colonies of the British Empire in the West Indies, South America, North America, Asia, Austral-Asia, Africa and Europe. London: W. H. Allen \& Co. and George Routledge.

Morris, T. O. (1952) The Water Supply Resources of Malta. Malta: The Government of Malta.

Office of the Prime Minister (1993) Geological Map of the Maltese Islands, Sheet 2: Gozo and Comino. Malta: Oil Exploration Directorate.

Ordnance Survey (1965) Malta, Sheets 3887, 3888, 4087 and 4088. British Government's Ministry of Overseas Development: Directorate of Overseas Surveys.

Samut-Tagliaferro, A. (1993) The Coastal Fortifications of Gozo and Comino. Valletta, Malta: Midsea Publications.

Spiteri, M. \& Borg, D. (2015) The formation of the architect-engineer, perito and agrimensore, and their regulation by the Order of St. John in eighteenth-century Malta, The Journal of Baroque Studies, Progress Press (Malta), 1 (3), 129-173.

Spiteri, S. (2008) The Art of Fortress Building in Hospitaller Malta 1530-1798. San Ġwann, Malta: BDL Publishing.

Spiteri, S. St Anthony Battery. [Online]

Available from http://www.militaryarchitecture.com/index.php/Fortifications/st-anthonybattery.html. [Accessed 3rd October 2016].

Vartic, L. (2015) Cartographical visual expression, a means of communication and exploration in architecture and art. Geographia Technica, 10 (1), 90-95. 